ELORE (ISSN 1456-3010), vol. 19 - 1/2012.

Julkaisija: Suomen Kansantietouden Tutkijain Seura ry.

[http://www.elore.fi/arkisto/1_12/mustamo.pdf]

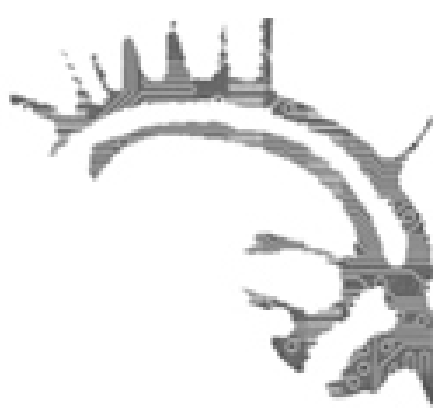

KIRJA-ARVIO

\title{
KERTOMAA SUOMEN VIIME SODASTA
}

STRANDÉN, SOFIE 2010: "I eld, i blod, i frost, $i$ svält". Möten med veteraners, lottors och sjuksköterskors berättande om krig. Åbo: Åbo Akademi. 437 sivua.

\section{$\underline{\text { Aila Mustamo }}$}

Talvi- ja jatkosodan tapahtumia ja niiden muistoja on pitkän vaikenemisen jälkeen alettu tutkia innokkaasti. Muistojen kirjaaminen jälkipolville on tärkeää siitäkin syystä, että sodan kokeneita ei kohta enää ole, mutta myös siksi, että kylmän sodan jälkeinen isänmaallisuus rakentuu pitkälti niiden varaan. Käsitykset sotien tapahtumista vaikuttavat erityisesti nuorten mielipiteisiin Suomesta ja suomalaisuudesta (esim. Virrankoski 2001). Sodilla ja veteraanien asialla perustellaan milloin mitäkin ajankohtaista yhteiskunnallista asiaa. Koska sotamuistojen avulla rakennetaan käsitystä meistä ja yhteiskunnasta, niiden tutkimuksella on merkitystä myös tiedeyhteisön ulkopuolella.

Folkloristi Sofie Strandén lähti kentälle tutkimaan Vänrikki Stoolin tarinoiden merkitystä sodan kokeneille ihmisille, mutta informantit halusivatkin kertoa hänelle omista sotamuistoistaan. Strandén päätyi lopulta kirjoittamaan väitöskirjan siitä, miten sodasta kerrotaan. Samalla kirja on tutkimus folkloristisesta tutkimusprosessista. Kun kolme tutkimusta kulkee rinnan samassa kirjassa, lukijan on välillä vaikea pysyä kärryillä. Tutkimusprosessin hajanaisuus näyttää heijastuvan myös kirjan rakenteeseen. Erilaisia aineksia kuljetetaan kirjassa rinnakkain. Kaikkialla ne eivät asetu loogiseksi kokonaisuudeksi, vaan hyppäykset aiheesta toiseen yllättävät lukijan. Olisi helpompi arvioida, miten hyvin kirjoittaja on onnistunut saavuttamaan työn tavoitteet, jos ne olisi kirjoitettu esiin selkeämmin. Nyt väitöskirjan tutkimusongelmaa pitää välillä etsiä rivien välistä. 
I eld, i blod, i frost, i svält täydentää suomalaista sotamuisto- ja lottatutkimusta. Erityisen kiinnostavan siitä tekee suomenruotsalaisen kielivähemmistön näkökulma. Nationalistisessa diskurssissa pyritään vähättelemään kansakunnan sisäisiä eroja ja esittämään kansakunta yhtenäisempänä kuin se oikeastaan onkaan. Strandénin tutkimustulokset osoittavat, että kieli- ja kulttuurierot jakoivat sodan kokenutta sukupolvea, mutta siitä huolimatta se pystyi ponnistelemaan yhteisten päämäärien hyväksi.

Kirja koostuu erittäin yksityiskohtaisesta ja laajasta metodiosuudesta ja varsinaisista analyysiluvuista, joiden pääteemat ovat sodanaikaisten tehtävien suorittaminen, ruumiilliset kokemukset ja kohtaamiset toiseuden kanssa. Haastatellut kertovat myös vaikeista vaikenemisen vuosista sodan jälkeen ja veteraanien ja lottien kunnian vähittäisestä palautuksesta.

Tutkimus sijoittuu konstruktivistisen ja postmodernistisen kulttuurintutkimuksen kenttään, mikä näkyy muun muassa menetelmien ja kenttätyötapahtumien saamassa huomiossa ja runsaassa itsereflektiossa. Keskeinen käsite on oral history. Voidaan kuitenkin pohtia, onko se työssä pikemminkin metodologinen kuin teoreettinen työkalu.

Tutkimuksessa tärkeintä on kerronnan eikä niinkään konkreettisten sotatapahtumien tutkimus. Strandén kuvailee informantteja ja haastattelutilanteita herkullisen yksityiskohtaisesti pohtien kuitenkin informanttien tunnistettavuuteen liittyviä ongelmia. Kenttätyökuvausten yhteydessä hän pohtii perusteellisesti omaa asemaansa kentällä ja tutkimuksentekoa prosessina. Ylipäätään aineistoa ja tutkimuksen tekoa on esitelty erittäin monipuolisesti. Lienee mielipidekysymys, missä määrin näinkin runsas itsereflektio auttaa todellisuudessa lukijaa arvioimaan tutkijan tulkintoja.

\section{ISÄNMAALLISET SUOMENRUOTSALAISET}

Tutkimus perustuu 20 sodan kokeneen henkilön haastatteluihin. Puolet haastatelluista on entisiä rintamamiehiä, toinen puoli lottia ja sotilassairaalan sairaanhoitajia. Kaikki ovat kotoisin ruotsinkieliseltä Pohjanmaalta. Kirja valottaakin sotamuistoja nimenomaan suomenruotsalaisten näkökulmasta.

Sodat merkitsivät suomalaisille myös toiseuden kohtaamista, kun eri alueilta kotoisin olevat ihmiset päätyivät kosketuksiin toistensa kanssa. Strandénin haastattelemat veteraanit, lotat ja sairaanhoitajat joutuivat Pohjanmaan lakeuksilta Karjalan metsiin. Vihollisen ja saksalaisten aseveljien lisäksi heille toiseutta edustivat myös suomenkieliset suomalaiset. Miehet taistelivat toki ruotsinkielisissä joukko-osastoissa, mutta lotat ja sairaanhoitajat joutuivat lähes ummikoina toimimaan suomenkielisessä ympäristössä. Naiset joutuivat kiusaamisenkin kohteiksi kielitaustansa vuoksi. Miehille toiseutta edustivat Uudenmaan ruotsinkieliset, joiden koettiin olevan erilaisia, vaikka heillä oli sama äidinkieli. Lukijan mielessä herääkin kysymys, olisiko väitetty sodanjälkeinen yhtenäiskulttuuri ollut lainkaan mahdollinen ilman erilaisiin alueellisiin kulttuureihin kuuluneiden suomalaisten keskinäisiä kontakteja sodan aikana.

Strandénin mukaan ruotsinkielisellä Pohjanmaalla ollaan isänmaallisia. Haastateltavat ovatkin olleet mukana erilaisten isänmaallisten järjestöjen toiminnassa. Strandén korostaa aivan oikein, ettei hän näe ruotsinkielisen Pohjanmaan sotaveteraaneja 
minään marginaaliryhmänä, mutta olisi mielenkiintoista pohtia enemmänkin, missä määrin esimerkiksi paikallisidentiteetti ja yhteiskunnalliset mielipiteet tai myöhempi toiminta veteraanijärjestöissä ovat vaikuttaneet heidän kertomuksiinsa verrattuna muiden ryhmien vastaaviin sotatarinoihin.

\section{ROMANTTISET IHANTEET JA SODAN TODELLISUUS}

Tutkimuksen lähtökohta, sotaveteraanien Vänrikki Stoolin tarinoille antamat merkitykset, olisi ansainnut laajemmankin käsittelyn. Nyt sitä käsitellään jokseenkin satunnaisesti sotamuistojen seassa. Ehkäpä samasta aineistosta voisi julkaista vaikka artikkelin, jossa keskityttäisin pelkästään Vänrikki Stooliin?

Muistan hyvin, kun luin Vänrikki Stoolin tarinoita ensimmäisen kerran lapsena ja ihastuin romanttisen hurmahengen kyllästämiin runoihin. Myöhemmin sodan ja uhrimielen ihailu myös kauhistutti. Strandén on havainnut samanlaisen ristiriidan Runebergin sotaromantiikan ja sodan kokeneen sukupolven välillä. Vaikka Vänrikki i Stoolin tarinoiden isänmaallisuus puhutteli, haastateltujen sotamuistot poikkeavat kirjan ihanteellisuudesta. Jotkut kyseenalaistavat esimerkiksi sankaruuden merkityksen sotakokemuksissaan.

Myyttiä puhdashenkisestä sodankäynnistä on viime aikoina pyritty purkamaan. Esimerkiksi Sari Näreen ja Jenni Kirveen toimittamassa Ruma sota-artikkelikokoelmassa (2008) käsitellään sodankäynnin makaaberia puolta. Myös Strandénin haastateltavien muistoissa ruma sota nousee esiin. Tutkija kuvaa, kuinka osa haastateltavista ei halunnut kertoa kipeimmistä kokemuksistaan nauhurin ollessa päällä. Haastateltavat puhuvat niin lottien huonosta maineesta, ruoan varastamisesta nälkään kuin rintamakarkuruudestakin.

Siinä missä Vänrikeki Stoolin tarinat oli tärkeä teos ennen sotia, myöhemmin sotakokemusten tulkkina on totuttu pitämään ennen kaikkea Väinö Linnan Tuntematonta sotilasta ja Yrjö Jylhän Kïrastuli-runokokoelmaa, jotka lienevät myös Runebergia tutumpia nuorille. Jatkotutkimuksen kannalta olisikin kiinnostavaa pohtia, millä tavoin sodan kokenut sukupolvi merkityksellistäisi niitä verrattuna esimerkiksi Vänrikki Stoolin tarinoibin.

Vaikka Strandénin tutkimuksen punainen lanka katoaa välillä aiheiden moninaisuuteen, se on aiheensa ja perusteellisen aineiston käsittelyn vuoksi erittäin kiintoisaa luettavaa. Kirjassa olisi tarpeeksi aineksia useampaankin tutkimukseen. Koska Strandén esittelee menetelmäosuudessa monipuolisesti tutkimushaastatteluihin liittyvää tieteellistä keskustelua, kirjaan kannattaa tarttua myös metodologisten kysymysten askarruttaessa. 
Aila Mustamo: Kertomaa Suomen viime sodasta

\section{KirJallisuUs}

NÄRE, SARI \& KIRVES, JENNI 2008: Ruma sota. Talvi-ja jatkosodan vaiettu historia. Helsinki: Johnny Kniga.

VIRRANKOSKI, OSMO 2001: Maa kallis isien. Tutkimus peruskoulun päättävien oppilaiden isänmaallisundesta, suvaitsevaisundesta ja etnisistä ennakeoluuloista. Turku: Kirja-Aurora.

Filosofian maisteri Aila Mustamo valmistelee Oulun yliopistossa kulttuuriantropologian väitöskirjaa kotimaan ja kansakunnan merkityksestä black ja folk metal -alakulttuureissa. 